\title{
LEAN AND AGILE MANAGEMENT SYNERGY IN CONSTRUCTION OF HIGH-RISE OFFICE BUILDING
}

\author{
P. NOWOTARSKI ${ }^{1}$, J. PASŁAWSKI ${ }^{2}$
}

\begin{abstract}
The aim of this article is to identify opportunities for using synergies obtained by incorporation of the two methods of management: Lean Management and Agile Management on the example of the process of column concreting. Despite the seemingly contradictory assumptions the two concepts complement each other in analysed example. The strategy is based on using the idea of "one piece flow" in accordance with the Lean Management which led to a reduction of costs due to increased turnover of formwork. At the same time the success of the project resulted in a significant dependence on the ability to provide a rapid response to changing conditions during in the maturation of concrete (depending on weather conditions, which can be expected on the basis of projections having different reliability). The simultaneous use of Lean and Agile Management allowed to achieve positive results for different scenarios of environment impact on the analysed process.
\end{abstract}

Keywords: Agile Management, Lean Management, High-Rise construction, column concreting

\section{INTRODUCTION}

Analyzing the realization of construction contracts there is a need to pay attention to the increasing problems manifested primarily by exceeded budget, delays in the implementation of individual stages, the claims of quality. This causes many disputes, often lead to claims, bankruptcy of enterprises etc. The factors encouraging these problems include:

- steadily increasing scale of construction projects (Kerzner 2013);

\footnotetext{
${ }^{1}$ MSc Eng., Piotr Nowotarski, Poznan University of Technology, Faculty of Civil and Environmental Engineering, ul. Piotrowo 5,60-965 Poznan, Poland, e-mail: piotr.nowotarski@put.poznan.pl

${ }^{2}$ Prof., DSc., PhD., Eng., Poznan University of Technology, Faculty of Civil and Environmental Engineering, ul. Piotrowo 5,60-965 Poznan, Poland, e-mail: jerzy.paslawski@put.poznan.
} 
- changes in the project management (also under construction) due to focus on customer requirements related to the concept of value management;

- problems with coordination of various possible stakeholders involved in the project (the considerable complexity of projects);

- long chains of quality (quality management difficulties resulting from the co-responsibility of the various participants in the construction process).

It seems that to solve these complex problems improvement of the methods of management of processes, projects and organizations involved in these projects can be helpful. Following steady progress in the field of production management the chances to implement methods used successfully in other areas of economy (Six Sigma, Flexible Systems Management, Agile Management, Lean Management, Real-Time Management etc.) are higher. It should be noted that in the introduction of this type of methods, the awareness of the specific nature of the construction industry is needed. Illustrator of the implementation of Lean Management in the construction industry is among others Matt (Matt 2013). Examples of an increasingly integrated approach is the use of Lean Management and Six Sigma (Arthur 2014), Lean Management and Green Management (Verrier 2016) as well as Lean, Green and Six Sigma (Banawi 2014).

The aim of this article is to demonstrate the beneficial effects of synergy based on the use of both Lean Management and Agile Management at the concreting of columns in high rise office buildings. The paper presents the idea of synergy between Lean Management based on limiting losses and maximizing the value and Agile Management based on flexible adaptation to a changing environment (internal and external). For the analyzed example it demonstrated that the use of the idea of Lean allowed for greater rotation of the column formworks, lowered costs and shorter lead times increased the pace of implementation, but also leaded to increased sensitivity of the schedule on changeable environments. Implementation of the work during the autumn-winter season in Poland generates significant threat on conditions during maturation of the concrete mix. Reducing risk is based on an appropriate modification of the concrete mix, which, combined with the monitoring of the processes in progress and the environment, is the basis for flexible tactics that create the Agile Management (frost resistance guaranteed in every case).

\section{Production management development}

Construction Management is a relatively new field of management of their specificity. Typical methods of management include the Critical Path Method (CPM) and Line of Balance (LOB). The 
effectiveness of these methods, especially in terms of non-deterministic approach is not at the best possible level.

In the years 1975-1995 (Levitt 2007), which are dated back to the development of methods referring to the overall development of methods of production management, (e.g. Application of computeraided design tools, databases, artificial intelligence, expert systems, visual tools for planning and executing construction), still the delay in construction management in relation to other sectors of the economy is visible. In 1995-2005 further progress in the field of the use of computers to facilitate communication was made (Internet, mobile technologies) with favoring the idea of collaborative project management. It was important to reduce the size and price of the sensors, which contributed to the dissemination of the idea of measuring on-line (also in the network) for the automation and optimization of processes. This idea is in relation to the operation of construction facilities and gives enormous traceability effects of use also in extreme situations (flood, hurricane, earthquake). The advancement of the use of computer systems for monitoring and control of construction machines and equipment creates opportunities not only to increase efficiency, but also improve the quality. More widespread use of BIM technology, as equivalent to the CIM in the overall of production management, should be also noted. Particularly preferred option seems to be the use of virtual modeling for the design, implementation and use of a buildings. Through successive iterations using Virtual Reality technology maximum compatibility to meet user requirements for buildings in the design phase of the construction project can be achieved. The use of simulation in virtual reality (before accepting the version of the document) allows e.g. an analysis of the flow of passengers at the railway station or airport during normal operation and in the situation of extreme events (e.g. failure of the system, fire, terrorist attack etc.). When making the final decision all stages of the life cycle should be taken into account with not only economic factors, but also environmental and social. An important fact is the shift of focus from the traditional minimizing the cost of construction of the facility to maximize value from the point of view of sustainable construction. Similar trends are observed in the field of quality management, which is steadily increasing its range of integration. Currently, a typical combination of quality management, Health and Safety and environmental management often takes into account the energy management and information security. Typical challenges in the field of Construction Management include:

1. Making up decisions on the basis of the analysis of the life cycle, taking into account the principles of sustainable construction.

2. Increasing the integration of all stakeholders in the process (which promotes the idea of BIM). 
3. Overcoming barriers in the introduction of new methods and technologies based on experience from other sectors of the economy (e.g. Lean Management, Six Sigma, Agile Management).

4. Adjusting the methods of planning and monitoring processes and the environment with the use of wireless technologies, drones etc. to collect information in real time and to develop decision-making procedures with the use of the idea of rapid adjustment to changing environment.

5. Using of opportunities to learn and gather knowledge on the basis of past experience (databases and advisory systems) with data mining techniques (fundamental problem is the collection, transmission and processing of vast amounts of information and use them to make decisions in the future).

From the point of view of the current challenges it is important to take into account the need to work in a dynamically changing environment where production conditions are far from stability which is typical for other areas of the economy.

\section{LEAN AGILE SYNERGY IDEA}

Based on the described development trends in the field of management, in general and in the construction industry, it can be said that a major problem is the incompatibility of planning and execution of construction processes, which take place in a dynamically changing environment. Seeking uniform theoretical basis, fundamental concept of Transfer-Flow-Value (Koskela 1999) should be indicated. It is based on three sub-theories that are oriented on transformation (for processing by machines and workers), flow (related materials and intermediates in the production) and value (aimed at meeting the needs of the customer). The first of these is interpreted generally as a reflection of the traditional approach based on the decomposition of the production process into tasks and minimizing the cost of all jobs (Table 1).

The second (Flow) is to reduce the share of activities not adding value by reducing the processing time, reducing variability, process simplification and increased flexibility. Third (Value) is to increase customer value based on meeting all of its requirements and provide adequate opportunities for their implementation in a production system.

In general analysis of different concepts aimed at improving management theory of construction production (Bertelsen and Bonke 2011, Koskela at al. 2007, Sarden and Stehn 2005) which streamline construction processes can be made through the use of outside approaches oriented at common 
problems in the management of construction production: (1) To reduce losses and increase productivity. (2) Respect the importance of customer value (assuming the ability to change the time of construction). (3) The ability to react to changes in a dynamically changing environment (internal and external).

Table 1. Principles of production in construction - TFV theory of production after Koskela

\begin{tabular}{|c|c|c|c|}
\hline & Transformation view & Flow view & Value generation view \\
\hline $\begin{array}{c}\text { Conceptual } \\
\text { ization of } \\
\text { production }\end{array}$ & $\begin{array}{c}\text { Transformation of } \\
\text { inputs into outputs }\end{array}$ & $\begin{array}{c}\text { Flow of material, } \\
\text { composed of } \\
\text { transformation, inspection, } \\
\text { moving and waiting }\end{array}$ & $\begin{array}{c}\text { Process where value for the customer is created } \\
\text { through fulfilment of his requirements }\end{array}$ \\
\hline $\begin{array}{c}\text { Main } \\
\text { principle }\end{array}$ & $\begin{array}{c}\text { Getting production } \\
\text { realized efficiently }\end{array}$ & $\begin{array}{c}\text { Elimination of waste (non- } \\
\text { value adding activities) }\end{array}$ & $\begin{array}{c}\text { Elimination of value loss (achieved value in } \\
\text { relation to best possible value) }\end{array}$ \\
\hline $\begin{array}{c}\text { Associated } \\
\text { principles }\end{array}$ & $\begin{array}{c}\text { Mecompose the } \\
\text { production task } \\
\text { all decomposed tasks }\end{array}$ & $\begin{array}{c}\text { Compress lead time, } \\
\text { reduce variability, } \\
\text { simplify, increase } \\
\text { transparency and } \\
\text { flexibility }\end{array}$ & $\begin{array}{c}\text { Ensure that: 1) all requirements get captured, 2) } \\
\text { the flow down of customer requirements, 3) } \\
\text { requirements for all deliverables are taken into } \\
\text { account, 4) the capability of production system, } \\
\text { and 5) measure the value }\end{array}$ \\
\hline
\end{tabular}

With a view to the possibility of advancement of the implementation of BIM, which is now in the analyzed cases focused on the analysis of three-dimensional model, e.g. from the point of view of the detection of potential collisions, or non-compliance of the project with the facts, it must be assumed that BIM will also support the solution to the above problems (Won et al. 2016, Liu et al. 2015, Zou at al. 2016). It seems especially important to the advancement of higher stages of BIM, when it will be possible to analyze the use of various materials and technological solutions for the virtual model and the results of their application, taking into account all phases of the life cycle from the point of view of the sustainable construction. However, due to the specific nature of typical construction problems, such as lack of stability of production processes, high dynamics of the environment they will remain valid and will require the use of appropriate methods. This does not exclude, of course, ways to support their implementation using BIM technology. From the point of view of sustainable construction four basic options should be considered (Azevedo et al. 2016): (1) Lean - understood as maximizing customer value and minimize losses; (2) Agile - as a concept focused on the ability to quickly and effectively respond to unforeseen changes; (3) Resilent - adopted a set of procedures aimed at preserving a balance in spite of unexpected disruptions; (4) Green - a set of good practices for reducing environmental risks while maintaining environmental effectiveness. 
To simplify the issue proposed solution is to introduce two methods of management: (1) Lean management; (2) Agile management.

The first serves to reduce losses and increase the efficiency of processes, which is equivalent to an increase of sensitivity to changes in the environment in which its activities are carried out. Except from typical categories of waste other authors (Plebankiewicz, Mitera 2016) are analyzing new possibilities connected with Lean Introduction. Prof. Sobotka team (Biruk et al. 2003) points at supporting Lean Management with others management methods. Positive effects of using Flexibility with Lean approach are based on the reduction of variability (Thomas et al. 2002).

Second, Agile Construction, aims to ensure a balance between environmental conditions and opportunities for the organization processes. In this approach (Daneshgari, 2010) very important are variants and aiming to quick adaptation for changing environment. In the interest of the organization it is to maintain the continuity of processes in spite of these changes, assuming the achievement of the assumed effects.

The adopted model assumes the desire to maintain a balance between the demands of the environment and the possibilities of implementation of the construction processes of the organization:

$$
E C \cdot R O \rightarrow E Q
$$

where:

$E C$ - environmental conditions, $R O-$ options of process realizations.

Using Ashby's law with necessary diversity it is assumed that, in order to ensure equilibrium organization must have a sufficient variety of ready to run controls, in response to the ambient conditions which may arise. If the system is in a given time $\mathrm{t}$ in equilibrium $E Q$, under condition of dispose necessary diversity $\varphi(x(t))$ possible operations control, which from the point of view of the expected results is sufficient under the assumption of possible changes in the environment, it provides a basis for achieving balance in the next stage $(t+\Delta t)$ :

$$
X_{e}(t) \in E Q \wedge(\forall x \in X \varphi(x(t))-(\psi(z(t)+v(t))) \geq 0) \Rightarrow X_{e}(t+\Delta t) \in E Q
$$

where:

$X e$ - set of states of equilibrium, $x(t)$ - current state of the system, $z(t)$ - current unpredictable disruption, $v(t)$ - current predictable disruption, $\varphi(x(t))$ - variability control, $\psi(z(t)+v(t))$ - interference diversity 
In order to achieve the necessary diversity systems flexibility is introduced, which in turn makes it possible to continue building processes, despite variations in environmental conditions. It is assumed that it is better to maintain a balance than take the risk of the operation without the necessary diversity of its maintenance (counting the occurrence of additional costs) ensuring the effective functioning despite the change in the conditions of implementation. Operating costs outside the state of equilibrium and of its re-restore cost justify the adoption of the proposed strategy.

The following example of concreting columns in high office building was used to check the effects of the use of two methods of management (Lean and Agile Management) to improve the processes on site, when adverse weather conditions could occur seems very probable.

\section{Case Study}

\subsection{BALTYK INFORMATION}

For the purposes of the case study authors examined the process of construction of the office building "Bałtyk" in Poznan (Poland). Visualization of the object is shown in Fig. 1. The construction began in November 2014, the completion of works was planned for February 2017. The building has a very interesting shape which refers to the local modernism from the architectural point of view. It will have 16 floors above ground and 3 underground.

Authors took into account one of the most common activities during basic stage of erection, which was the execution of reinforced concrete columns. Majority of columns have height of $3.15 \mathrm{~m}$. with diameters ranging from $0.40 \mathrm{~m}$ to $0.70 \mathrm{~m}$. The total number of columns at the entire facility taken into account is 144 pieces. Columns were carried out using formwork consisting of a semi-circular elements (Fig.1), working platform, the platform supports, the vertical supports, ladders, barriers entry.
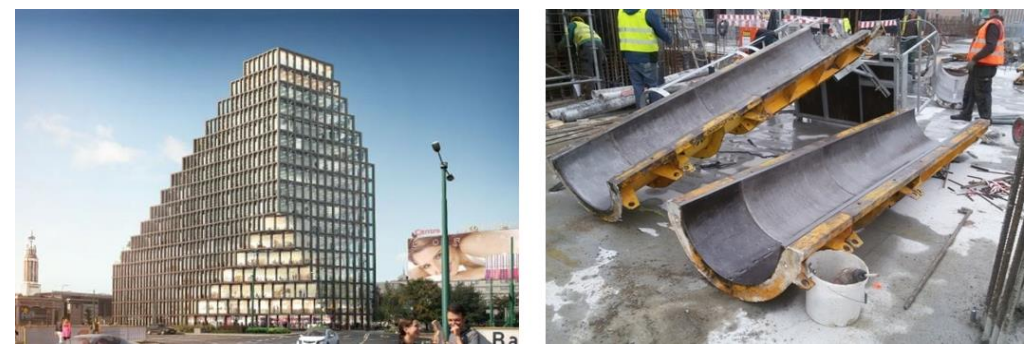

Fig. 1. Visualisation of the object (left) and columns formwork(right). 


\subsection{SCHEDULES DESCRIPTION}

Authors decided to show how Lean Management can influence the total time of performing activities. Talking into account possible disruptions in the schedule. To do so totally 4 schedules were prepared. First schedule is showing operation of preparing columns before introduction of Lean Management ideas (Fig. 2, left). This corresponds to the situation on the construction site when execution from ten to twelve columns on one scale-interval work area at once (together there were two scale-interval work areas per single floor) was done, so each time on the construction site a minimum of 12 sets of formwork molds had to be available. This involved substantial costs associated with the need to store and assembly formwork for longer time. There was also a need to wait for formwork removal on the whole scale-interval work area, before taking any further steps in construction process. The total time from the beginning of each floor to the moment of concreting the slab was 10 working days.

Then authors prepared schedule with implemented Lean Management principles (Fig. 2, right). The idea was to introduce uniform working methods and thus the separation of larger quantity of working areas. From the initial division of two parcels A and B, additional 3 working plots A1, A2, A3 in the initial plot A and 3 working plots B1, B2, B3 in the initial plot B were created (Fig.4). By reducing
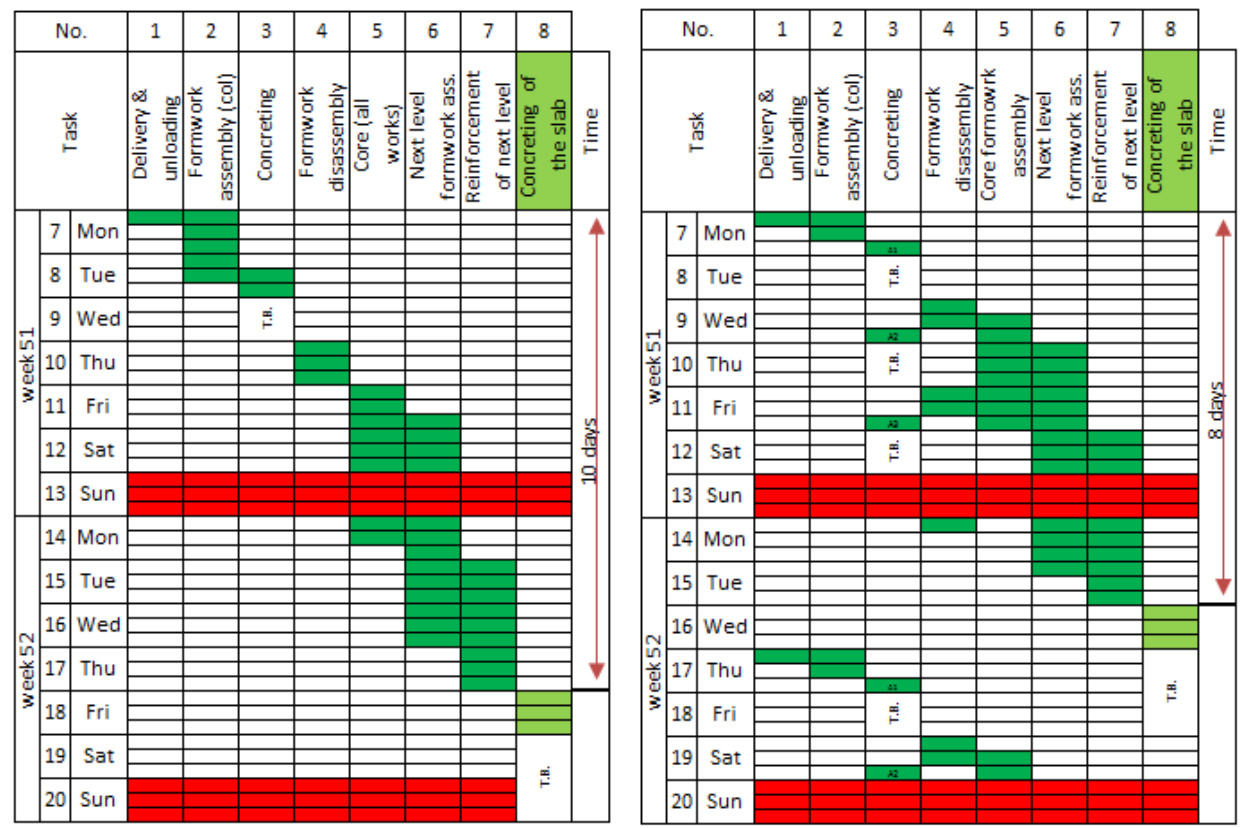

Fig. 2. Schedule without adverse weather conditions and without introduction LM (left), and with LM (right). 
the work area, the amount of simultaneously required formwork decreased to 4 sets. The methodology used is similar to the concept of "one piece flow" (reduction of concrete columns from 12 to 4 per working plot, which allowed the implementation of further works after the removal of the formwork on reduced working plots). Thanks to this solution in the organization of the work, reduction of the number of carpenters involved in the formwork assembly working simultaneously was possible. Moreover, the lowering of costs associated with renting formwork molds and reducing time between finishing columns formworks and concreting the next floor were also observed which now took 8 working days.
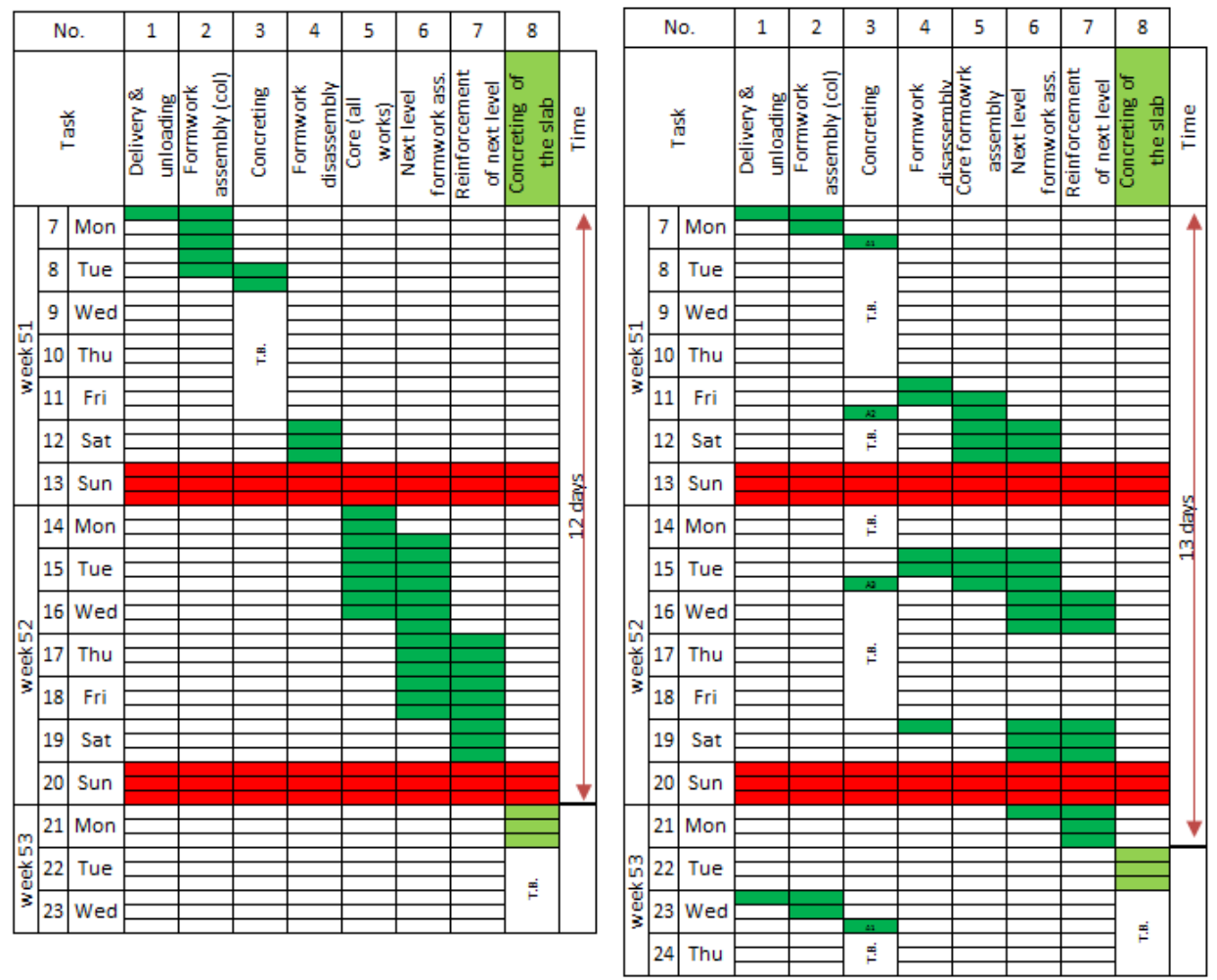

Fig. 3. Schedule with adverse weather conditions and without introduction LM (left), and with LM (right).

After preparing basic schedules authors tried to figure out how changing environmental conditions can influence on the modified and basic schedule. To do so, authors performed simulation of adverse weather conditions (low temperatures) and decided to show how this conditions influence on the 
schedules in comparison with basic situation and Lean Management methods. Authors assumed that during adverse weather conditions technological break will have to take instead of 1day (in normal conditions) 3 days. Results are shown in Figure 3 with the modified schedules before and after introduction of Lean Management principles.

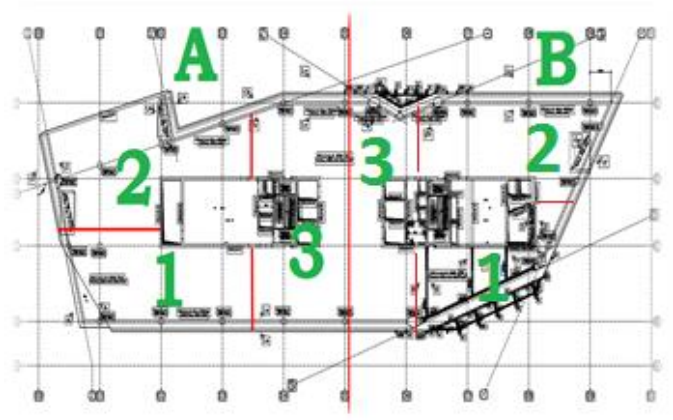

Fig. 4. Example of working plots division.

It is clearly visible that with adverse weather conditions total time of erecting analysed slab is quicker without introduction of Lean Management ideas (12 days to 13 days). The reason for such situation is the fact, that with LM version 3 times concreting of columns is performed instead of 1, so each time 2 days are lost during adverse weather conditions.

To prevent such actions authors propose introduction of flexibility connected with changing the concrete mix. Possible solutions for temperature $+5^{\circ} \mathrm{C}$ are presented in Table 2 .

Table 2. Example of concrete strength for $+5^{\circ} \mathrm{C}$ options for different concrete mix depending on time with relation to cost.

\begin{tabular}{|c|c|c|c|c|}
\hline \multirow{2}{*}{ Mixture } & \multicolumn{3}{|c|}{ Strenght [MPa] after } & \multirow{2}{*}{ Cost } \\
\cline { 2 - 5 } & 1 day & 1,5 day & 3 days & $100 \%$ \\
\hline M1 & 1,5 & 2 & 3,3 & $101 \%$ \\
\hline M2 & 2,9 & 3,2 & 18,7 & $102 \%$ \\
\hline M3 & 5,5 & 8,7 & 18,9 & $103 \%$ \\
\hline M4 & 10 & 13,7 & 14,4 & $108 \%$ \\
\hline M5 & 10 & 10 & 17,6 & $114 \%$ \\
\hline
\end{tabular}


Changing the concrete mix (Using M3 instead of M1) will require from responsible person to predict adverse weather conditions and change the order for concrete for designated area. This will allow to introduce Lean Management principles independently from changing weather conditions and will prevent from causing delays.

\section{CONCLUSIONS}

Analysis of the concept of the use of synergy based on simultaneous application of Lean Management and Agile Management illustrated on the example of concreting columns in the construction of a high office building allows to formulate the following conclusions:

1. The introduction of Lean Management reduces losses and increases the efficiency of the process (higher turnover formwork by using uniform working methods lowered the cost of renting formwork), but also leads to increased sensitivity of the schedule to the conditions of concrete maturing.

2. Application of variants (in line with the idea of Agile Management) of concrete mix enables to reach required frost resistance of concrete needed to proceed according to the schedule regardless of the adverse weather conditions.

3. The use of both Lean Management and Agile Management streamline the process of concreting columns leading to the reduction of costs in formwork lease at the level of $66 \%$ and shorten the lead time of approx. $20 \%$. On this background increase in costs of the proposed concrete mix by $2 \%$ appears to be small.

The authors predict further studies to estimate the effects of the implementation of various methods of management in the construction industry with emphasis on the idea of sustainable construction.

\section{ACKNOWLEDGEMENTS}

The authors thanks to employees of the company performing the processes on site, and in particular to site engineer Mr Jakub Matyja. The publication was created with the support of statutory funds of Institute of Structural Engineering at Poznan University of Technology no. DSPB11-602/2016. 


\section{REFERENCES}

1. J. Arthur, "Lean six sigma, a fresh approach to achieve quality management", Quality Management Journal, 21:6-9, 2014

2. S.G. Azevedo, H. Carvalho, V. Cruz-Machado," LARG index. A benchmarking tool for improving the leanness, agility, resilence and greenness of automotive supply chain”, Benchmarking: An Int. Journal, 1472-1499, 2016.

3. A. Banawi, M.M. Bilec, "A framework to improve construction process: integrating lean, green and six sigma, International Journal of Construction Management, 14 (1), 45-55, 2014

4. S. Bertelsen, S. Bonke, "Transformation-flow-value as a strategic tool in project production", Proceedings of 19th International Group for Lean Construction Conference, 2011.

5. S. Biruk, P. Jaskowski, A. Sobotka „Zarzadzanie w budownictwie”, Wyd. Politechniki Lubelskiej, Lublin, 2003

6. P. Daneshgari, “Agile construction for the electrical contractor”, Mass.: Jones and Bartlett Publishers, 2010.

7. H. Kerzner, "Project Management system approach for planning, scheduling and controlling",11th Ed Wiley 2013.

8. L. Koskela, J.Rooke, S. Bertelsen, G. Henrich, "The TFV theory of production: new developments", Proceedings of 15th International Group for Lean Construction Conference, 2007.

9. L. Koskela, "Management of production in construction: a theoretical view", 7th International Group for Lean Construction Conference, Berkeley, 241-252, 1999.

10. R.E. Levitt, "CEM research for next 50 years: maximizing economic, environmental, and societal Value of the built environment", Journal of Construction Engineering and Management, 133:619-628, 2007.

11. Z. Liu, M. Osmani, P. Demian, A. Baldwin, "A BIM-aided construction waste minimalisation framework", Automation in construction, 59: 1-23, 2015.

12. D. Matt, "Adaptation of the values stream mapping approach to the design of lean engineer-to-order production systems. A case study", Journal of manufacturing Technology, 25:334-350, 2014

13. E. Plebankiewicz, E. Mitera "Wastes on construction site", Materiały Budowlane, 6/2016: 184-185.

14. R. Thomas, M. Horman, U.E.L de Souza, I. Zavirski "Reducing variability to improve performance as a lean construction principle", Journal of Construction Engineering and Management, 128:144-154, 2002

15. B. Sertyesilisik, 2014. Lean and agile construction project management: as a way of reducing environmental footprint of the construction industry. In: Optimization and Control Methods in Industrial Engineering and Construction. Intelligent Systems, Control and Automation: Science and Engineering, 72: 179-196, 2014

16. Y. Sarden, L. Stehn, "Manging transformation, flow and value generation: a solid timber frame housing case", Association of Researchers in Construction Management, ARCOM 2005 - Proceedings of the 21st Annual Conference, 1:331-340, 2005.

17. B. Verrier, B. Rose, E. Caillaud, "Lean and green strategy: the lean and green house and maturity deployment model", Journal of cleaner production, 116:150-156, 2016

18. J. Won, J.C.P. Cheng, G. Lee, "Quantification of construction waste prevented by BIM-based design validation: case studies in South Korea”, Waste Management, 49: 170-180, 2016.

19. Y. Zou, A. Kiviniemi, S.W. Jones, "A review of risk management through BIM and BIM-related technologies", Safety Science [In Press], 2016. 


\section{LIST OF FIGURES AND TABLES:}

Tab. 1. Principles of production in construction - TFV theory of production after Koskela 2000.

Tab. 1. Zasady produkcji w budownictwie - teoria produkcji TFV wg. Koskela 2000.

Tab. 2. Example of concrete strength for $+5^{\circ} \mathrm{C}$ options for different concrete mix depending on the time with relation to cost.

Tab. 2. Przykłady wytrzymałości betonu dla zmiany temperatury o $+5^{\circ} \mathrm{C}$ dla różnych mieszanek betonowych w zależności od czasu wiązania z uwzględnieniem kosztu.

Fig. 1. Visualisation of the object and columns formwork.

Rys. 1. Wizualizacja obiektu i deskowanie słupów.

Fig. 2. Schedule without adverse weather conditions and without LM (left), and with LM (right).

Rys. 2. Harmonogram bez niekorzystnych warunków pogodowych i bez LM (lewo) oraz z LM (prawo).

Fig. 3. Schedule with adverse weather conditions and without LM (left), and with LM (right).

Rys. 3. Harmonogram z niekorzystnymi warunkami pogodowymi i bez LM (lewo) oraz z LM (prawo).

Fig. 4. Working Plot division.

Rys. 4. Podział na działki robocze. 


\section{SYNERGIA METODOLOGII LEAN MANAGEMENT I AGILE MANAGEMENT PRZY BUDOWIE BUDYNKóW WYSOKICH}

Slowa klucze: Lean Management, Agile Management, budynki wysokie, betonowanie słupów

\section{STRESZCZENIE:}

Analizując realizację kontraktów budowlanych należy zwrócić uwagę na narastające problemy przejawiające się przede wszystkim w przekroczeniu budżetu, opóźnieniach realizacji poszczególnych etapów, zastrzeżeniach jakościowych. Powoduje to liczne spory, często prowadzące do procesów sądowych, upadłości przedsiębiorstw, itp.

Do czynników sprzyjających wspomnianym problemom zaliczyć można:

- zwiększającą się systematycznie skalę przedsięwzięć budowlanych (Kerzner 2013),

- zmiany w trakcie realizacji projektu z racji koncentracji na wymaganiach klienta związanych z ideą zarządzania wartością (Value Management)

- problemy z koordynacją różnych branż uczestniczących w przedsięwzięciu (znaczny stopień skomplikowania przedsięwzięć),

- d dugie łańcuchy jakości (trudności z zarządzaniem jakością wynikające ze współodpowiedzialności różnych uczestników procesów budowy),

- $\quad$ relatywnie niską wydajność produkcji w porównaniu z pozostałymi działami gospodarki.

Wydaje się, że do rozwiązania tych skomplikowanych problemów może się przyczynić doskonalenie metod zarządzania procesami, przedsięwzięciami i organizacjami zaangażowanymi w tych projektach. Śledząc systematyczny postęp wdziedzinie zarządzania produkcją można dostrzec szanse polegające na implementacji metod stosowanych z powodzeniem w innych dziedzinach działalności gospodarczej (Six Sigma, Flexible Management Systems, Agile Management, Lean Management, Real Time Management, itp.). Należy jednocześnie zwrócić uwagę, że wprowadzenie tego typu metod ze świadomością specyficznych wymagań uwzględnienia specyfiki budownictwa. Zastosowanie metod Lean Management w budownictwie pokazane było przez m.in.: Matt’a (Matt 2013). Przykładami coraz bardziej zintegrowanego podejścia jest zastosowanie Lean Management i Six Sigma (Arthur 2014), Lean Management and Green Management (Verrier et al. 2016) oraz lean, green i Six Sigma (Banawi 2014). Podstawowym efektem zastosowania jednocześnie różnych metod zarządzania jest osiągnięcie równowagi gwarantującej lepsze efekty niż wynikające z zastosowania pojedynczej metody. zarządzania. Przykład omawiany w niniejszym artykule wskazuje na konieczność wprowadzenia różnych opcji realizacji procesów wobec zwiększenia ryzyka zakłóceń związanych z działaniem w dynamicznie zmiennym otoczeniu.

Celem artykułu jest wykazanie korzystnego efektu synergii na podstawie zastosowania jednocześnie Lean Management i Agile Management przy betonowaniu słupów w wysokim budynku biurowym (Biurowiec Bałtyk w Poznaniu - Rys. 1). W niniejszym artykule przedstawiono ideę synergii pomiędzy Lean Management opartym na ograniczeniu strat i maksymalizacji wartości z Agile Management bazującym na elastycznym dostosowaniu do zmiennego otoczenia (wewnętrznego i zewnętrznego). Na analizowanym przykładzie budowy wykazano, że zastosowanie idei Lean pozwala na uzyskanie większej rotacji urządzeń formujących (niższe koszty) oraz skrócenie czasu realizacji (zwiększenie tempa realizacji), jednak jednocześnie prowadzi to do zwiększenia wrażliwości zmodyfikowanego harmonogramu na zmienne otoczenie. Realizacja robót w okresie jesienno-zimowym w Polsce generuje znaczne zagrożenie warunków dojrzewania mieszanki betonowej. Ograniczenie ryzyka bazuje na odpowiedniej modyfikacji mieszanki betonowej, co w połączeniu 
z monitorowaniem procesów w toku i otoczenia oraz wiarygodną prognozą pogody stanowi podstawy elastycznych taktyk składających się na Agile Management.

Analiza koncepcji zastosowania synergii bazującej na jednoczesnym zastosowaniu Lean Management i Agile Management zilustrowana przykładem betonowania słupów przy budowie wysokiego budynku biurowego pozwala na wyciągnięcie następujących wniosków:

1. Wprowadzenie Lean Management ogranicza straty i podnosi efektywność procesu (większa rotacja deskowań przy użyciu metod pracy równomierniej zmiejszyła koszty wynajmu deskowań), jednak prowadzi jednocześnie do zwiększenia wrażliwości harmonogramu na warunki dojrzewania betonu

2. Zastosowanie wariantowania (zgodnie z ideą Agile Management) mieszanki betonowej umożliwia osiągniecie wymaganej dojrzałości(wytrzymałości mrozowej) betonu pozwalając na realizację prac zgodnie z harmonogramem niezależnie od warunków otoczenia

3. Dzięki zastosowaniu jednocześnie Lean Management i Agile Management osiągnięto usprawnienie procesu betonowania słupów prowadzące do ograniczenia kosztów w granicach $66 \%$ związanych z kosztem wynajmu deskowania oraz skrócenie czasu realizacji na poziomie ok. $20 \%$. Na tym tle zwiększenie kosztów mieszanki betonowej o $2 \%$ wydaje się niewielkie.

Autorzy przewidują dalsze badania mające na celu oszacowanie efektów wprowadzenia różnych metod zarzadzania w budownictwie $\mathrm{z}$ uwzględnieniem idei budownictwa zrównoważonego. 
